\title{
Pengaruh Kemampuan Matematika dan Motivasi Belajar Terhadap Kemampuan Fisika Siswa SMA Negeri 4 Palu
}

\author{
Anggun Ika Pristanti, Amiruddin Hatibe, dan Sahrul Saehana \\ anggunikapristanti@gmail.com \\ Program Studi Pendidikan Fisika FKIP Universitas Tadulako \\ Jl. Soekarno Hatta Km. 9 Kampus Bumi Tadulako Tondo Palu - Sulawesi Tengah
}

\begin{abstract}
Abstrak - Permasalahan dalam penelitian ini adalah ada tidaknya pengaruh kemampuan matematika dan motivasi belajar siswa. Penelitian ini bertujuan untuk mengetahui adanya pengaruh kemampuan matematika dan motivasi belajar terhadap kemampuan fisika siswa SMA Negeri 4 Palu. Populasi dalam penelitian ini adalah siswa kelas X SMA Negeri 4 Palu tahun ajaran 2016/2017 yang terdiri dari 7 kelas. Sampel yang digunakan diambil dengan menggunakan teknik simple random sampling, dengan asumsi bahwa ketujuh kelas homogen. Pengumpulan data adalah dilakukan dengan menggunakan tes dan angket yang telah di validasi oleh validator. Data yang diperoleh dianalisis menggunakan teknik korelasi product moment. Hasil penelitian menunjukkan koefisien korelasi antara kemampuan matematika dengan hasil belajar fisika siswa yaitu sebesar $r_{y l}=0,908$ kemudian uji signifikansi dilakukan dengan cara membandingkan $t_{\text {hitung }}$ dengan $t_{\text {tabel. }}$. Berdasarkan hasil perhitungan dengan menggunakan uji-t maka diperoleh $t_{\text {hitung }}=12,638$ sedangkan dari tabel distribusi $t$ pada taraf signifikansi $\mathrm{a}=0,05 \mathrm{dan} \mathrm{dk}=34$ diperoleh $\mathrm{t}_{\text {tabel }}=2,04$. Jadi $\mathrm{t}_{\text {hitung }}$ ini yang berarti Ho ditolak. Disimpulkan bahwa terdapat hubungan yang signifikan antara kemampuan matematika dengan kemampuan fisika. Koefisien korelasi antara motivasi belajar dengan kemampuan fisika siswa yaitu sebesar $r_{y l}=0,647$ kemudian uji signifikansi dilakukan dengan cara membandingkan $t_{\text {hitung }}$ dengan $t_{\text {tabel. Berdasarkan hasil }}$ perhitungan $t_{\text {hitung }}$ dengan menggunakan uji-t maka diperoleh thitung $=6,492$ sedangkan dari tabel distribusi $t$ pada taraf signifikansi $a=0,05 \mathrm{dan} d \mathrm{~d}=34$ diperoleh $\mathrm{t}_{\text {tabel }}=2,04$. Jadi $t_{\text {hitung }}>\mathrm{t}_{\text {tabel }}$ yang berarti Ho ditolak. Disimpulkan bahwa terdapat hubungan yang signifikan antara motivasi belajar dengan kemampuan fisika. Kemampuan matematika dan motivasi belajar berpengaruh positif dan signifikan terhadap kemampuan fisika siswa dengan analisis korelasi ganda dan uji-F diperoleh koefisien korelasi sebesar 0,680, $F_{\text {hitung }}$ sebesar 14,214 dan $F_{\text {tabel }}$ pada taraf signifikan 0,05 , db pembilang 2 dan $\mathrm{dk}$ penyebut 36 adalah 3,06 , melalui persamaan regresi linier ganda $Y=4,492+0,01 X_{1}+0,349 X_{2}$, sehingga hipotesis yang diajukan dapat diterima
\end{abstract}

Kata kunci: Kemampuan Matematika, Kemampuan Fisika dan Motivasi Belajar.

\section{PENDAHULUAN}

Fisika adalah ilmu pengetahuan yang mempelajari proses-proses alam dan interaksi yang terjadi antara bagian-bagian alam tersebut, termasuk menerapkan sifat-sifat dan gejala-gejalanya. Sedangkan matematika memegang peran sangat penting dalam menjelaskan konsep fisika. Rumus matematis akan memberikan kesederhanaan dalam menjelaskan konsep maupun memudahkan dalam memahami gejala fisika. Disamping itu dalam pembelajaran juga perlu memperhatikan motivasi belajar pada siswa agar siswa dapat terdorong untuk menguasai pelajaran yang telah disampaikan oleh guru Jadi pada dasarnya seseorang yang memahami konsep matematika dan memiliki motivasi belajar akan dengan mudah menyelesaikan soal-soal fisika dan tidak menyerah dalam mengerjakan soal ketika mendapatkan kesulitan yang memerlukan perhitungan matematika. [7]

Menurut Riyadi mata pelajaran fisika adalah salah satu mata pelajaran dalam rumpun sains yang dapat mengembangkan kemampuan berfikir analisis induktif dan deduktif dalam menyelesaikan masalah yang berkaitan dengan peristiwa alam sekitar serta dapat mengembangkan pengetahuan, keterampilan dan sikap percaya diri. Dalam pelajaran fisika siswa tidak hanya belajar konsep hukum atau rumus, tetapi juga belajar bagaimana membahas masalah fisika yang dapat berupa soal-soal. Banyaknya rumus dan soal-soal hitungan pada pelajaran fisika membuat siswa dituntut memiliki kemampuan matematika yang lebih agar dapat menyelesaikan soal-soal dengan mudah.

Dwi menyimpulkan bahwa terdapat hubungan yang signifikan antara kemampuan matematika dengan hasil belajar yang dicapai siswa dalam pembelajaran fisika. Mengenalkan seseorang terhadap prestasi belajarnya adalah penting, karena dengan mengatahui hasil-hasil yang sudah dicapai maka siswa akan lebih berusaha meningkatkan prestasi belajarnya. Dengan demikian peningkatan prestasi belajar dapat lebih optimal karena siswa tersebut merasa termotivasi untuk meningkatkan prestasi belajar yang telah diraih sebelumnya. [1] 
Mushawir dan Nurul menyimpulkan bahwa Salah satu faktor rendahnya hasil belajar siswa adalah kurangnyaa perhatian guru memperhatikan hal-hal yang bisa memotivasi siswa dalam belajar. Kualitas suatu proses pembelajaran, selain dipengaruhi oleh model pembelajaran yang diterapkan di kelas, juga dipengaruhi oleh karakteristik siswa. Salah satu karakteristik siswa yang dapat mempengaruhi keberhasilan penerapan suatu model pembelajaran adalah motivasi belajar siswa. Motivasi belajar merupakan daya penggerak individu untuk melakukan kegiatan belajar untuk menambah pengetahuan, keterampilan dan pengalaman. [6]

Dorongan motivasi dalam belajar merupakan salah satu hal yang perlu dibangkitkan dalam meningkatkan kemampuan belajar siswa terutama dalam materi fiska. Ketika guru tidak mengetahui seberapa besar motivasi belajar siswa akan sangat kesulitan dalam menyampaikan pembelajaran. Ketika dalam kelas guru hanya menggunakan pembelajaran yang hanya monoton tanpa mengetahui seberapa besar motivasi belajar akibatnya siswa kurang bersemangat dalam belajar dan tidak berani untuk mengungkapkan ide-ide yang dimiliki oleh siswa. Sehingga kebanyakan siswa tidak mengerti tentang materi yang disampaikan. Jadi jangan heran jika banyak siswa yang menunggu jawaban dari teman. Motivasi berkaitan dengan sejumlah keterlibatan siswa dalam aktivitas di kelas seperti dorongan untuk melakukan sesuatu berdasarkan tujuan tertentu, kebiasaankebiasaan, kebutuhan kebutuhan dan hasrat tertentu. [8]

Hal ini akan erat kaitannya dalam usaha untuk mencapai tujuan belajar fisika. Berdasarkan latar belakang masalah yang telah dikemukakan di atas, dapat dirumuskan masalah penelitian sebagai berikut "Apakah ada pengaruh kemampuan matematika terhadap kemampuan fisika dan motivasi belajar siswa SMA Negeri 4 Palu" Penelitian ini betujuan untuk menjawab rumusan masalah atau pertanyaan-pertanyaan yang telah dirumuskan di atas. Secara rinci mempunyai tujuan ada tidaknya pengaruh kemampuan matematika dan motivasi belajar terhadap kemampuan fisika siswa SMA Negeri 4 Palu.

\section{METODE PENELITIAN}

Metode penelitian ini menggunakan metode penelitian asosiatif korelasional. Pada penelitian ini, yakni variabel bebas adalah kemapuan matematika dan motivasi belajar siswa kelas $X$
IPASMA Negeri 4 Palu dan variabel terikat adalah kemampuan fisika siswa kelas X IPASMA Negeri 4 Pau.

Penelitian ini dilaksanakan pada semester ganjil tahun akademik 2016/2017, di SMA NEGERI 4 Palu. Sampel penelitian ini mengambil salah satu kelas X IPA SMA Negeri 4 Palu. Teknik pengambilan sampelnya adalah simpel random sampling, dengan asumsi bahwa ketujuh kelas homogen.

Instrumen penelitian berupa angket yang terdiri atas tes kemampuan matematika dan tes kemampuan fisika dan angket motivasi belajar. Data penelitian di uji dengan mengggunakan micorsof exel.

\section{HASIL DAN PEMBAHASAN}

Hasil Uji Normalitas Variabel kemampuan matematika $\left(X_{1}\right)$ adalah $X^{2}$ hitung $=6,10681$, kemampuan fisika adalah $X^{2}$ hitung $=5,328$ dan motivasi belajar $\left(X_{2}\right)$ adalah $X^{2}$ hitung $=5,111$. Dengan masing-masing $X^{2}$ tabel $=7,81$.

Ringkasan uji normalitas semua variabel diperoleh harga-harga $\mathrm{X}^{2}$ hitung $<\mathrm{X}^{2}$ tabel dengan taraf a $=0,05$ yang berarti dapat disimpukan bahwa skor variabel kemampuan matematika ,kemampuan fisika dan motivasi belajar berdistribusi normal. Hasil Pengujian hipotesis yaitu, $\mathrm{H}_{1}=$ Ada pengaruh antara kemampuan matematika dan motivasi belajar terhadap kemampuan fisika. $\mathrm{H}_{2}=$ Tidak ada pengaruh antara kemampuan matematika dan motivasi belajar terhadap kemampuan fisika. regresi linier sederhana antara variabel $X_{1}$ dengan $Y$

Dengan mengambil variabel kemampuan matematika $\left(X_{1}\right)$ sebagai variabel bebas dan kemampuan fisika sebagai variabel terikat $(Y)$, maka pola hubungan antara kedua variabel dapat diketahui dengan cara analisis regresi $Y$ atas $X_{1}$ dan diperoleh persamaan regresi linieritas dapat dilihat pada Tabel 1.

TABEL 1 MENENTUKAN PERSAMAAN REGRESI LINIER SEDERHANA ANTARA VARIABEL $X_{1}$ DENGAN $Y$

$\widehat{Y}=12,632+0,908 x$

\begin{tabular}{lcc}
\hline \multicolumn{1}{c}{ Variabel } & $r_{y 1}$ & $t_{\text {hitung }}$ \\
\hline $\begin{array}{l}\text { Kemampuan Matematika terhadap } \\
\text { kemampuan fisika }\end{array}$ & 12,632 & 0,908 \\
\hline
\end{tabular}

Koefisien bernilai positif artinya pengaruh antara kemampuan matematika dengan kemampuan fiska siswa adalah positif yang berarti semakin tinggi kemampuan matematika maka akan semakin meningkat pula kemampuannya di bidang fisika. Pengujian hipotesis untuk mengetahui apakah ada pengaruh antara kemampuan matematika dan 
motivasi beajar terhadap

kemampuan

fisika. Hipotesis matematisnya:

$\mathrm{H}_{1}: \rho \neq 0$

$\mathrm{H}_{2}: \rho=0$

$\mathrm{H}_{1}=$ Ada pengaruh antara kemampuan matematika dan motivasi belajar terhadap kemampuan fisika.

$\mathrm{H}_{2}=$ Tidak ada pengaruh antara kemampuan matematika dan motivasi belajar terhadap kemampuan fisika

Menentukan persamaan regresi linier sederhana antara variabel $X_{2}$ dan $Y$. Dengan mengambil variabel motivasi belajar $\left(X_{2}\right)$ sebagai variabel bebas dan kemampuan fisika sebagai variabel terikat (Y), maka pola hubungan antara kedua variabel dapat diketahui dengan cara analisis regresi $Y$ atas $X_{1}$ dan diperoleh persamaan regresi linieritas dapat dilihat pada tabe 2 .

TABEL 2 MENENTUKAN PERSAMAAN REGRESI LINIER SEDERHANA ANTARA

\begin{tabular}{ccc}
\multicolumn{4}{c}{ VARIABEL X2 DENGAN Y } \\
\hline \multicolumn{3}{c}{$\widehat{Y}=6,492+0,647 x$} \\
\hline Variabel & $r_{\mathrm{yl}}$ & $t_{\text {hitung }}$ \\
\hline $\begin{array}{l}\text { Motivasi Belajar terhadap } \\
\text { kemampuan fisika }\end{array}$ & 6,492 & 0,647 \\
\hline
\end{tabular}

Koefisien bernilai positif artinya pengaruh antara motivasi belajar dengan kemampuan fisika siswa adalah positif yang berarti semakin tinggi motivasi belajar maka akan semakin meningkat pula kemampuannya di bidang fisika. Untuk mengetahui hubungan linieritas antara variabel $X_{1}$ dan variabel $X_{2}$ secara bersama-sama terhdap variabel $Y$ dengan menggunakn persamaan regresi linier ganda.

TABEL 3 MENENTUKAN PERSAMAAN REGRESI LINIER GANDA ANTARA VARIABEL $X_{1}$ DAN VARIABEL $X_{2}$ TERHADAP $Y$ $\widehat{Y}=4,492+0,01 X_{1}+0,349 X_{2}$

\begin{tabular}{lccc}
\multicolumn{1}{c}{ Variabel } & $\alpha_{0}$ & $\alpha_{1}$ & $\alpha_{2}$ \\
\hline $\begin{array}{l}\text { Kemampuan matematika dan } \\
\text { motivasi belajar }\end{array}$ & 4,492 & 0,01 & 0,349 \\
\hline
\end{tabular}

Berdasarkan persamaan di atas dapat disimpulkan bahwa setiap pertambahan kemampuan matematika siswa sebesar 0,01 dan setiap pertambahn motivasi belajar siswa sebesar 0,349 akan berambah pula kemampuan fisika siswa.

Hasil penelitian dan analisis data dapat dikemukakan bahwa skor tertingi kemampuan matematika siswa adalah 90 dan terendah adalah 56 dengan standar deviasi adalah 10,85. Untuk hasil pengujian hipotesis mempunyai pengaruh terhadap hasil belajar fisika siswa. Hal ini dapat dilihat dari nilai korelasi yang didapatkan $r_{y l}=0,908$ dan kontribusi kemampuan matematika $82,446 \%$ dengan harga $t_{\text {hitung }}=12,632$ dan $t_{\text {tabel }}=2$, 04. Ini berati thitung $>$ ttabel maka koefisisen korelasi $X_{1}$ dan $Y$ signifikan pada taraf nyata $a=0,05$ dapat diterima.

Dari hasil data pengujian hipotesis yang diperoleh diketahui bahwa terdapat hubungan secara signifikan antara kemampuan matematika dan kemampuan fisika siswa. Dibuktikan pada penelitian yang telah dilakukan Dwi menyimpulkan bahwa terdapat hubungan yang signifikan antara kemampuan matematika dengan hasil belajar yang dicapai siswa dalam pembelajaran fisika. Siswa yang memiliki kemampuan matematika baik dapat diprediksi memiliki kemampuan dalam memahami konsep fisika dan kemampuan dalam menyesaikan soal-soal perhitungan fisika, sehingga dapat meningkatkan hasil belajar siswa.

Untuk tes motivasi belajar siswa terhadap kemampuan fisika, skor tertinggi yang diperoleh siswa adalah 86 dan skor terendah adalah 62. Nilai rata-rata yang diperoleh 76,72 dengan standar deviasi 8,86. Besarnya koefisien korelasi yang didaptkan adalah $r_{y l}=$ 0,647 dan kontribusi terhadap kemampuan fisika sebesar $0,419 \%$ dengan harga thitung $=$ 6,492 dan tabel $=2,04$. Ini berarti bahwa thitung $>$ tabel. Maka koefisien korelasi $X_{2}$ dan $Y$ signifikan pada taraf nyata $a=0,05$ data diterima.

Dalam hal ini, peran motivasi belajar siswa terhadap kemampuan fisika sangat penting. Hal ini sesuai dengan penelitian yang telah dilakukan oleh Handayani ada hubungan motivasi belajar terhadap hasil berprestasi siswa. Motivasi belajar berpengaruh dalam kemampuan fisika siswa. Dalam hal ini, siswa yang memilki motivasi tertentu akan cenderung atau menolak suatu objek berdasarkan penilaian terhadap objek itu, berguna baginya atau tidak. Dengan demikian jika siswa memiliki motivasi belajar yang tinggi maka akan berpengaruh positif terhadap kemampuan fisika siswa karena akan semakin mudah dalam memahami materi yang diberikan. [4]

Hasil Pengujian hipotesis kemampuan matematika dan motivasi belajar siswa terhadap kemampuan fisika memberikan nilai korelasi sebesar $R=0,680$ dan kontribusi kemampuan matematika dan motivasi belajar siswa sebesar $46,24 \%$ dengan harga $F_{\text {hitung }}=$ 14,214 dan $F_{\text {tabel }}=3,06$ dan dari uji $t$ diperoleh $\mathrm{t}_{1}=5,100$ dan $\mathrm{t}_{2}=18,368>\mathrm{t}_{\text {tabel }}=2,04$. Dengan demikian koefisien regresi $X_{1}$ dan $X_{2}$ bersifat signifikan. Pada hasil penelitian menjelaskan bahwa, kemampuan matemtika dan motivasi sangat mempengaruhi pada peningakatan hasil belajar siswa. Hal ini dapat dibuktikan pada pengujian determinasi 
koefisien korelasi pada kemampuan matematika berkontribusi $82,45 \%$ dan motivasi belajar $41,86 \%$. Dapat disimpulkan bahwa kemampuan matematika dan motivasi belajar mempengaruhi kemampuan siswa pada mata pelajaran fisika. Berdasarkan pembahasan hasil di atas, dapat disimpulkan mengenai diterima atau ditolaknya hipotesis, yaitu:

1. Hipotesis 1.

$\mathrm{H}_{0}$ ditolak dan $\mathrm{H}_{1}$ diterima yang berarti ada pengaruh kemampuan matematika terhadap kemampuan fisika

2.Hipotesis 2.

$\mathrm{H}_{0}$ ditolak dan $\mathrm{H}_{2}$ diterima yang berarti ada pengaruh Motivasi Belajar terhadap kemampuan fisika.

\section{KESIMPULAN DAN SARAN}

\section{A. Kesimpulan}

Berdasarkan kesimpulan peneitian ini, dapat disimpulkan bahwa terdapat pengaruh kemampuan matematika dan motivasi belajar siswa SMA Negeri 4 Palu.

B. Saran-Saran

1. Dalam proses pembelajaran fisika hendaknya memperhatikan faktor dari dalam diri siswa seperti motivasi belajar siswa

2. Untuk meningkatkan pembelajaran fisika di sekolah perlu diperhatikan peningkatan pembelajaran mata
p-ISSN 2338 3240/e-ISSN 25805924

pelajaran lain yang sejalan, dalam hal ini mata pelajaran matematika

3. Penelitian selanjutnya perlu ditambahkan variabel lain yang terlibat dalam populasi penelitian dan memperbaiki cara pengumpulan data yang dilakukan.

\section{DAFTAR PUSTAKA}

[1] Dwi. (2015) Hubungan antara Kemampuan Matematika dengan Hasil Belajar Siswa dalam Pembelajaran Fisika di Kelas X SMA Negeri 3 Lubuklinggau. Lubuklinggau.

[2] Hamdu dan Agustina. (2011). Pengaruh motivasi belajar siswa terhadap prestasi belajar IPA di sekolah Dasar (Studi kasus terhadap siswa SD Kelas IV Tarumanagara). Universitas Pendidikan Indonesia.

[3] Handayani. R. (2010) Hubungan Motivasi Belajar Terhadap Prestasi Belajar Geografi Siswa Kelas $X$ dan XI IPS SMA N 1 Minggir Sleman Tahun Ajaran 2009/2010. Universitas Negeri Yogyakarta.

[4] Mushawir dan Nurul. (2015). Hubungan Gaya Belajar dan Motivasi Belajar dengan Hasil Belajar Biologi Siswa Kelas XI IPA SMA Negeri 1 Tanete Rilau. Universitas Negeri Makasar

[5] Putri. (2012).Pengaruh Virtual Experiment Terhadap Hasil Belajar Fisika Ditinjau dari Motivasi Belajar Siswa SMA Negeri 1 Singaraja. Jornal Pasca Undiksha

[6] Riyadi. (2013). Studi Korelasi Penalaran Konsep Fisika dan Penalaran Matematika terhadap Hasil Belajar Siswa di SMAN 15 Surabaya pada Pokok Bahasan Gerak Parabola. Jurnal Inovasi Pendidikan Fisika. 2 (3), 75-79.

[7] Sugiyono. (2013). Pengaruh Metode Pembelajaran Pemecahan Masalah, Retensi Belajar, dan Motivasi Beajar terhadap Hasil Belajar Siswa SMK. Univeristas Negeri Malang. 